Egypt. Acad. J. biolog. Sci., 1(1): 1- 6 (2009)

Email: egyptianacademic@yahoo.com

Received: 2/8/2009

\section{F. Toxicology \&Pest control \\ ISSN: 2090 - 0791 \\ www.eajbs.eg.net}

\title{
Laboratory bioassay of some entomopathogenic fungi on Spodoptera littoralis (Boisd.) and Agrotis ipsilon (Hufn.) larvae (Lepidoptera: Noctuidae).
}

\author{
El-Hawary, F.M and Abd El-Salam, A.M.E \\ Pests and Plant Protection Department, National Research Centre, \\ El-Tahrir St., Dokki, Cairo, Egypt
}

\begin{abstract}
Efficacy of entomopathogenic fungi products (i.e. Bio- Power (Beauveria bassiana), Bio-Catch (Lecanicillium lecanii) and Priority (Paecilomyces fumosoroseus)) against Spodoptera littoralis and Agrotis ipsilon larvae were evaluated under laboratory conditions. Four different concentrations i.e. $0.125 \times 10^{9}, 0.25 \times 10^{9}$, $0.5 \times 10^{9}$ and $1 \times 10^{9}$ spores/ $1000 \mathrm{ml}$ D.W of each formulation were used against each pest under investigation and compared with control insects. The results obtained show that Bio- Power was the most effective product followed by Bio-Catch and Priority against $S$. littoralis $3^{\text {rd }}$ instar larvae, whereas, the $\mathrm{LC}_{50,90}$ values were $0.2 \times 10^{9}$ and $1.5 \times 10^{9}, 0.22 \times 10^{9}$ and $4.6 \times 10^{9}, 0.44 \times 10^{9}$ and $4.7 \times 10^{9}$, respectively. While in case of A. ipsilon, Priority was the most potent product followed by Bio- Power and BioCatch, whereas, the $\mathrm{LC}_{50,90}$ values were $0.14 \times 10^{9}$ and $0.6 \times 10^{9}, 0.2 \times 10^{9}$ and $0.9 \times 10^{9}$, $0.4 \times 10^{9}$ and $9.7 \times 10^{9}$, respectively. Also, The results obtained show that percentage mortalities of treated third instar larvae of $S$. littoralis with Bio- Power, Bio-Catch and Priority were 87.5,72.5 and 67.5\%, respectively, within 6.3,8.2 and 7.4 days at the highest concentration used $\left(1 \times 10^{9}\right.$ spores). However, The treated third instar larvae of A. ipsilon with Priority, Bio- Power and Bio-Catch achieved 100, 90.0 and $62.5 \%$ mortality, respectively, within 5.3, 7.1 and 3.9 days at concentration of $1 \times 10^{9}$ spores. The different formulations had delayed effects, the percentage of pupae and adults emerged were significantly decreased with an increase in concentrations.
\end{abstract}

Key words: Spodoptera littoralis; Agrotis ipsilon; Entomopathogenic fungi; Beauveria bassiana; Lecanicillium lecanii; Paecilomyces fumosoroseus.

\section{INTRODUCTION}

Over-reliance on broad-spectrum pesticides had come under severe criticism from different parts of the world after the publication of Silent spring in 1962 by Rachel Carson. Since then, an alternative ecofriendly strategy for the management of noxious insect pests has been searched to reduce harmful effects of chemical insecticides on humanity. Studies of biodiversity in agroecosystems and the delivery of ecosystem services to agricultural production have usually ignored the contribution of entomopathogens in the regulation of pest populations (Altieri, 1999; Gurr et al., 2003; Tscharntke et al., 2005). In recent years, crop protection based on biological control of crop pests with microbial pathogens like virus, bacteria, fungi and nematodes has been recognized as a valuable tool in pest management (Bhattacharya et al., 2003). The appropriate use of environment-friendly microbial pesticides can play a significant role in sustainable crop production by providing a stable pest management program. Among the fungi, several asexual fungi are associated with Arthropods, especially with insects. Entomopathogenic fungi that parasitize insects are valuable weapons for biocontrol and play an important role in promoting integrated pest management. To date, various strains of entomopathogenic 
fungi such as Lecanicillium (previous name, Verticillium) sp. (Jackson et al., 1985; Steenberg and Humber, 1999; Jung et al., 2006), Beauveria bassiana (Quesada et al., 2006), and Paecilomyces (Shia and Feng, 2004), have been used to control aphids, lepidopteran larva and other pests. Therefore, for successful establishment of B. bassiana, L. lecanii, P.

\section{MATERIALS AND METHODS} Commercial Formulations:

A number of commercial formulations of the entomopathogenic formulation were liquid products, BioPower (containing $1 \times 10^{9}$ Beauveria bassiana spores/ml), Bio-Catch (containing $1 \times 10^{9}$ Lecanicillium lecanii spores $/ \mathrm{ml}$ ) and Priority (containing $1 \times 10^{9}$ Paecilomyces fumosoroseus spores/ml) were obtained from T. Stanes Company limited, India.

Insects used

Newly moulted $3^{\text {rd }}$ instar larvae of Spodoptera littoralis and Agrotis ipsilon were obtained from sensitive culture reared for several generations on castor leaves under laboratory conditions $\left(27.0 \pm 1.0^{\circ} \mathrm{C}\right.$ $\& 70.0 \pm 5.0 \% \mathrm{RH})$.

\section{Experiments:}

Mortality Bioassay

Serial dilutions were prepared in $1000 \mathrm{ml}$ distilled water for each formulation $\left(0.125 \times 10^{9}, 0.25 \times 10^{9}, 0.5 \times 10^{9}\right.$, $1 \times 10^{9}$ spores / $1000 \mathrm{ml}$ D.W). Ten $3^{\text {rd }}$ instar larvae for $S$. littoralis or A. ipsilon in a Petri dish $(9 \mathrm{~cm}$ diameter) lined with a filter paper were sprayed with $2.0 \mathrm{ml}$ from each concentration per each formulation using a hand atomizer or hand sprayer (JSGW, Ambala, India). After air drying, the treated larvae were carefully transferred to individual sterile round plastic vials $\left(4.5 \times 12.0 \mathrm{~cm}^{2}\right)$ containing fresh pieces of castor leaves (larva / vial). The vials had screw caps having provision for proper aeration. Larvae were maintained in an incubator at $27.0 \pm 1.0^{\circ} \mathrm{C}$ and adjusting the relative humidity to $70.0 \pm 5.0 \% \mathrm{RH}$. Another group, 10 larvae sprayed with distilled water and reared under the above mentioned conditions, served as control. Mortality was counted daily and the lethal concentration of 50 and $90 \%$ from treated larvae was calculated by Probit analysis fumosoroseus and to reduce insecticidal treatment in IPM program, the role of these fungi is very important. The present study was conducted for evaluating some Entomopathogenic fungi products against Spodoptera littoralis and Agrotis ipsilon as polyphagous insect pests.

(Finney, 1971). Also, the mean number of days for larval mortality was calculated as shown below:

$$
\begin{aligned}
& X_{1} y_{1}+X_{2} y_{2}+X_{n} y_{n} \\
\text { Mean time to death (days) }= & \text { Total } x \text { mortality }
\end{aligned}
$$

where $x$ is the number of larvae that mortality occur on a given day and $y$ is the number of days from when the trial was initiated; 1, 2 and $\mathrm{n}$ are the first, second and last day of observation, respectively (Edde and Amatobi (2003). The percentage reduction in mortality of larvae were calculated and corrected according to Abbott' s formula (1925).The experiment was replicated 4 times (10 larvae / replicate). Also, the percentage pupation and adult emergence were recorded for each formulation and concentrations used.

\section{RESULTS AND DISCUSSION}

Toxic effect of entomopathogenic fungi against $S$. littoralis and $A$. ipsilon $3^{\text {rd }}$ instar larvae.

The results in Table (1) show that S. littoralis $3^{\text {rd }}$ instar larvae that treated with Bio-Power were highly affected whereas, the fifty and ninety lethal concentrations values were $0.2 \times 10^{9}$ and $1.5 \times 10^{9}$ spores $/ 1000 \mathrm{ml}$. while Bio-Catch $\begin{array}{llll}\text { achieved } & 0.22 \times 10^{9} \text { and } 4.6 \times 10^{9}\end{array}$ spores $/ 1000 \mathrm{ml}$,respectively for $\mathrm{LC}_{50,90}$ values. However, Priority was the least toxic products. On the other hand, $A$. ipsilon $3^{\text {rd }}$ instar larvae that treated with Priority was highly affected where $\mathrm{LC}_{50,90}$

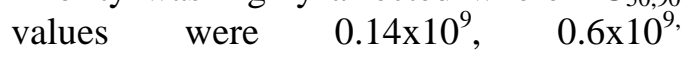
respectively. The other two products tested were less effective. Sabbour and Sahab, (2007) showed that the $\mathrm{Lc}_{50} \mathrm{~S}$ of the entomopathogenic fungi Beauveria bassiana, Metarhizium anisopliae and Verticillium lecanii, when applied to greasy cutworm, A. ipsilon were 137, 156, and 178 spores/ml, respectively. 
Hassani et al., (2000) found that $3^{\text {rd }}$ instar larvae of $S$. littoralis treated with $P$. fumosoroseus spores at $1 \times 10^{8}$ achieved $88.5 \%$ mortality during 7.6 days.

Table (1): Lethal concentrations of some entomopathogenic fungi against $S$. littoralis and A. ipsilon larvae

\begin{tabular}{|c|c|c|c|c|c|c|c|c|c|c|c|c|}
\hline \multirow{3}{*}{$\begin{array}{c}\text { Formulation } \\
\mathrm{s}\end{array}$} & \multicolumn{6}{|c|}{ S. littoralis } & \multicolumn{6}{|c|}{ ipsilon } \\
\hline & \multicolumn{4}{|c|}{ Spores/1000ml D.W* } & \multirow{2}{*}{$\begin{array}{c}\text { Slop } \\
\mathrm{e}\end{array}$} & \multirow[t]{2}{*}{$\mathrm{X}^{2}$} & \multicolumn{4}{|c|}{ Spores/1000ml D.W } & \multirow{2}{*}{$\begin{array}{c}\text { Slop } \\
\mathrm{e}\end{array}$} & \multirow[t]{2}{*}{$\mathrm{X}^{2}$} \\
\hline & \multirow[t]{2}{*}{$\mathrm{LC}_{50}$} & \multirow[b]{2}{*}{$0.2 \times 10^{9}$} & $\begin{array}{c}\text { Lower } \\
\text { limit }\end{array}$ & $\begin{array}{l}\text { Upper } \\
\text { limit }\end{array}$ & & & \multirow[t]{2}{*}{$\mathrm{LC}_{50}$} & \multirow[b]{2}{*}{$0.2 \times 10^{9}$} & $\begin{array}{c}\text { Lower } \\
\text { limit }\end{array}$ & $\begin{array}{l}\text { Upper } \\
\text { limit }\end{array}$ & & \\
\hline \multirow[b]{2}{*}{ Bio-Power } & & & $0.13 \times 10^{9}$ & $0.3 \times 10^{9}$ & \multirow[b]{2}{*}{1.5} & \multirow[b]{2}{*}{1.0} & & & $0.15 \times 10^{9}$ & $0.3 \times 10^{9}$ & \multirow[b]{2}{*}{2.0} & \multirow[b]{2}{*}{0.4} \\
\hline & $\mathrm{LC}_{90}$ & $1.5 \times 10^{9}$ & $0.9 \times 10^{9}$ & $5.1 \times 10^{9}$ & & & $\mathrm{LC}_{90}$ & $0.9 \times 10^{9}$ & $0.65 \times 10^{9}$ & $1.8 \times 10^{9}$ & & \\
\hline \multirow[t]{2}{*}{ Bio-Catch } & $\mathrm{LC}_{50}$ & $\underset{9}{0.22 \times 10}$ & $0.1 \times 10^{9}$ & $0.38 \times 10^{9}$ & \multirow[t]{2}{*}{0.99} & \multirow[t]{2}{*}{0.09} & $\mathrm{LC}_{50}$ & $0.4 \times 10^{9}$ & $0.3 \times 10^{9}$ & $1.0 \times 10^{9}$ & \multirow[t]{2}{*}{0.9} & \multirow[t]{2}{*}{0.2} \\
\hline & $\mathrm{LC}_{90}$ & $4.6 \times 10^{9}$ & $1.6 \times 10^{9}$ & $4.9 \times 10^{9}$ & & & $\mathrm{LC}_{90}$ & $9.7 \times 10^{9}$ & $2.6 \times 10^{9}$ & $20.0 \times 10^{9}$ & & \\
\hline \multirow{2}{*}{ Priority } & $\mathrm{LC}_{50}$ & $0.4 \underset{9}{0.40} 10$ & $0.3 \times 10^{9}$ & $0.7 \times 10^{9}$ & \multirow{2}{*}{1.24} & \multirow{2}{*}{0.75} & $\mathrm{LC}_{50}$ & $0.14 \times 10^{9}$ & $0.1 \times 10^{9}$ & $0.2 \times 10^{9}$ & \multirow{2}{*}{2.01} & \multirow{2}{*}{1.5} \\
\hline & $\mathrm{LC}_{90}$ & $4.7 \times 10^{9}$ & $1.9 \times 10^{9}$ & $5.4 \times 10^{9}$ & & & $\mathrm{LC}_{90}$ & $0.6 \times 10^{9}$ & $0.4 \times 10^{9}$ & $1.1 \times 10^{9}$ & & \\
\hline
\end{tabular}

*D.W= distilled water

Toxic effect and mean time to death.

Data in Table (2) indicate that the percentage mortality of the larvae increased with increasing concentrations of both pathogens however, the mean time to death decreased as the spores concentration increased. Also, Bio-Power was the most effective against $S$. littoralis $3^{\text {rd }}$ instar larvae. While, in case of $A$. ipsilon $3^{\text {rd }}$ instar larvae, Priority was the most effective. Bio-Power at high concentration $\left(1.0 \times 10^{9}\right)$ achieved $87.5 \%$ mortality for S. littoralis within 6.3 days while Priority at high concentration $\left(1.0 \times 10^{9}\right)$ achieved $100 \%$ mortality for $A$. ipsilon within 5.3 days. Tounou et al., (2008) found that when $M$. anisopliae applied at $1 \times 10^{3}$ and $11 \times 10^{4}$ spores/Schistocerca gregaria nymph the Median survival time estimates for these treatments were $18.8 \pm 0.6$ and $12.3 \pm 0.9$ days, respectively. Mortality increased with increasing concentrations of both pathogens and with the time interval between the two treatments.

Table (2): Toxic effect of some Entomopathogenic fungi against Spodoptera littoralis and Agrotis ipsilon $3^{\text {rd }}$ instar larvae.

\begin{tabular}{|c|c|c|c|c|c|}
\hline \multirow{2}{*}{ Formulations } & \multirow{2}{*}{$\begin{array}{l}\text { Conc. } \\
\text { spores } / 1000 \mathrm{ml} \\
\text { D.W* }\end{array}$} & \multicolumn{2}{|c|}{ Spodoptera littoralis } & \multicolumn{2}{|c|}{ Agrotis ipsilon } \\
\hline & & $\%$ mortality & $\begin{array}{l}\text { Mean time to larval } \\
\text { mortality (days) } \pm \mathrm{SE}\end{array}$ & $\%$ mortality & $\begin{array}{l}\text { Mean time to larval } \\
\text { mortality (days) } \pm S E\end{array}$ \\
\hline \multirow{4}{*}{ Bio-Power } & $0.125 \times 10^{9}$ & 40.0 & $12.1 \pm 1.2$ & 32.5 & $11.0 \pm 1.9$ \\
\hline & $0.25 \times 10^{9}$ & 50.0 & $10.2 \pm 2.3$ & 52.5 & $9.2 \pm 2.9$ \\
\hline & $0.5 \times 10^{9}$ & 67.5 & $7.1 \pm 1.5$ & 80.0 & $8.5 \pm 3.3$ \\
\hline & $1.0 \times 10^{9}$ & 87.5 & $6.3 \pm 2.5$ & 90.0 & $7.1 \pm 1.2$ \\
\hline \multirow{4}{*}{ Bio-Catch } & $0.125 \times 10^{9}$ & 37.5 & $15.1 \pm 1.6$ & 27.5 & $7.9 \pm 1.6$ \\
\hline & $0.25 \times 10^{9}$ & 52.5 & $13.2 \pm 2.15$ & 42.5 & $6.1 \pm 1.7$ \\
\hline & $0.5 \times 10^{9}$ & 62.5 & $11.5 \pm 2.64$ & 50.0 & $5.4 \pm 2.5$ \\
\hline & $1.0 \times 10^{9}$ & 72.5 & $8.2 \pm 2.7$ & 62.5 & $3.9 \pm 2.1$ \\
\hline \multirow{4}{*}{ Priority } & $0.125 \times 10^{9}$ & 27.5 & $10.6 \pm 1.8$ & 50.0 & $11.0 \pm 2.2$ \\
\hline & $0.25 \times 10^{9}$ & 32.5 & $7.8 \pm 2.41$ & 62.5 & $9.1 \pm 1.4$ \\
\hline & $0.5 \times 10^{9}$ & 55.0 & $5.6 \pm 1.98$ & 87.5 & $7.2 \pm 3.1$ \\
\hline & $1.0 \times 10^{9}$ & 67.5 & $7.4 \pm 2.2$ & 100 & $5.3 \pm 2.2$ \\
\hline
\end{tabular}

Quesada-Moraga and Vey, (2004) found that injection of

Bassiacridin (B. bassiana content ) at a dose of $2.8 \mu \mathrm{g} / \mathrm{g}$ to fourth instar nymphs of the locusts Locusta migratoria, Schistocerca gregaria and Dociostaurus maroccanus, and to fifth instar larvae of the lepidopterans Galleria mellonella and Spodoptera littoralis, and of the coleopteran Tenebrio molitor. Bassiacridin was not toxic to $S$. littoralis and T. molitor, whereas it was slightly toxic to $G$. mellonella causing $16.6 \%$ corrected mortality. In contrast, it was equally toxic to the migratory locusts $L$. migratoria and to the desert locust $S$. gregaria, with mortality rates of 42.5 and $38.3 \%$ respectively, and slightly more toxic to the Moroccan locust D. maroccanus, causing 49.2\% mortality. Hassani et al., (2000) stated that $P$. fumosoroseus is highly virulent against these three important cotton pests (Spodoptera littoralis, 
Helicoverpa armigera and Aphis gossypii).

Delayed effects of the entomopathogenic fungi on the resulted stages

The entomopathogenic fungi Beauveria bassiana (Bio-Power) had delayed effect on the tested pests. The percentage pupation from treated $S$. littoralis larvae were 32.5 and $12.5 \%$ at concentration of $0.5 \times 10^{9}$ and $1.0 \times 10^{9}$ spores $/ 1000 \mathrm{ml}$.
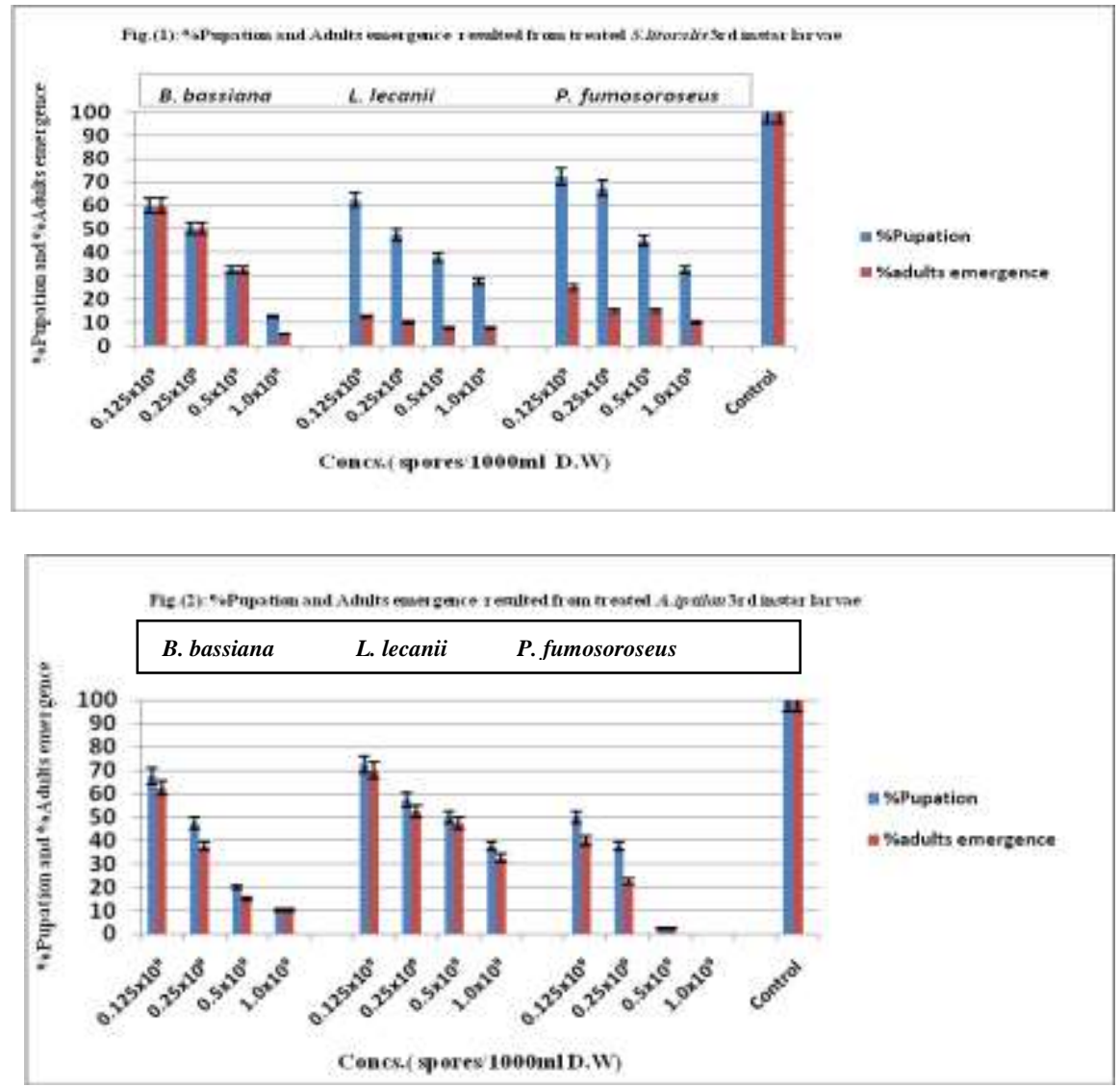

Figs. (1\&2): The percentage pupation and the adults emergence of S. littoralis and A. ipsilon $3^{\text {rd }}$ instar larvae treated with entomopathogenic fungi products ( Bio- Power (Beauveria bassiana), BioCatch (Lecanicillium lecanii) and Priority (Paecilomyces fumosoroseus)). Means ( \pm SE).

The percentage adults obtained decreased to $5.0 \%$ at $1.0 \times 10^{9}$ spores $/ 1000 \mathrm{ml}$ but there is no effect at 0.5 $\mathrm{x} 10^{9}(32.5 \%$ pupae continued to adults Fig.(1). S. littoralis that treated with $L$ .lecanii spores (Bio-Catch) at all concentrations used cause delaying effects, whereas, each survived larvae that pupated failed to emerge to adults i.e. at concentration of $1.0 \times 10^{9}$, the percentage pupation was $27.5 \%$ decreased $7.5 \%$ adults emergence. Also, $P$ fumosoroseus spores (Priority) affected the percentage of adults emergence Fig. (1).In case of treated larvae of A. ipsilon with the fungi of $P$. fumosoroseus (Priority), the percentage pupation decreased to $2.5 \%$ at concentration of $0.5 \times 10^{9}$ Fig. (2).

The results were in agreement with the findings of Altre and Vandenberg (2001) who found that Paecilomyces fumosoroseus penetrated the cuticle and proliferation in hemolymph of diamondback moth, Plutella xylostella and fall armyworm, Spodoptera frugiperda larvae within $22 \mathrm{~h}$ after inoculation at the concentration of $4 \times 10^{5}$ spores.

The percentage mortality was 91.0 and $54.0 \%$ of Plutella xylostella and Spodoptera frugiperda, respectively. 
Hicks et al., (2001) stated that the mean time to death decreased as the conidial $B$. bassiana dose increased when treated fifth instar larvae of Panolis flammea. The concentrations were $4.8 \times 10^{3}, 4.8 \times 10^{4}$ and $4.8 \times 10^{5}$ caused mortality within 11,8 and 5 days, respectively. Shaw et al.,(2002) found that three isolates of $M$. anisopliae, one of $V$. lecanii, and one of $B$. bassiana killed $100 \%$ of Varroa destructor within 7 days at a conidial concentration of $1 \times 10^{8}$ $\mathrm{ml} / 1$. One isolate of $P$.fumosoroseus also killed $97 \%$ of $\mathrm{V}$. destructor within 7 days at a conidial concentration of $1 \times 10^{8} \mathrm{ml} / 1$. Smith et al., (2006) found that $90.0 \%$ mortality of Prostephanus truncatus was observed after 1 week and $100 \%$ mortality after 2 weeks in maize treated with the highest dose of conidia of Beauveria bassiana with ash $(0.2 \mathrm{~g} / \mathrm{g})$.

From the results obtained from the present studies is could be concluded that Beauveria bassiana (Bio-Power) was more potent against $S$. littoralis. However, $P$. fumosoroseus (Priority) was more potent against $A$. ipsilon.

\section{REFERENCES}

Abbott, W.S. (1925). A method of computing the effectiveness of an insecticide. J. Econ. Entomol 18 (2):265 -267.

Altre, A. and Vandenberg, D. (2001). Penetration of cuticle and proliferation in hemolymph by Paecilomyces fumosoroseus isolates that differ in virulence against lepidopteran larvae. J. Invert. Pathol 78: 81-86.

Altieri, M.A. 1999.The ecological role of biodiversity in agroecosystems. Agr. Ecosyst. Environ. 74:19-31.

Bhattacharya, A.K.; Mondal, P.; Ramamurthy, V.V. and Srivastava, R.P. (2003). Beauveria bassiana: a potential bioagent for innovative integrated pest management programme. In: Srivastava, R.P. (Ed.), Biopesticides and Bioagents in Integrated Pest Management of Agricultural Crops. International Book Distributing Co. Lucknow 860 $\mathrm{pp}$.

Edde, P. A. and Amatobi, C. I. (2003). Seed coat has no value in protecting cowpea seed against attack by Callosobruchus maculatus (F.). J. Stored Prod. Res. 39:1-10.

Finney, D.F. (1971). Probit analysis $3^{\text {rd }}$ edition. Cambridge University, London.

Gurr, G.M.; Wratten, S.D. and Luna, J.M. (2003). Multi-function agricultural biodiversity: pest management and other benefits. Basic Appl. Ecol. 4:107-116.

Hassani, M.; Zimmermann, G. and Vidal, S. (2000). Paecilomyces fumosoroseus: efficacy against the cotton pests Spodoptera littoralis (Lepidoptera: Noctuidae), Helicoverpa armigera (Lepidoptera: Noctuidae) and Aphis gossypii (Homoptera: Aphididae) and effect of temperature on germination and mycelial growth. Bulletin - OILB / SROP.23(2):217-221.

Hicks, B.; Watt, A. and Cosens, D. (2001). The potential of Beauveria bassiana (Hyphomycetes : Moniliales) as a biological control against the pine beauty moth, Panolis flammea (Lepidoptera: Noctuidae). Fore. Ecol. Manag, 149:275-281.

Jackson, C.W.; Heale, J. B. and Hall, R. A. (1985). Traits associated with virulence to the aphid Macrosiphoniella samborni in eighteen isolates of Verticillium lecanii. Ann. Appl. Biol., 106:39- 48.

Jung, H. S.; Lee, H. B.; Kim, K. and Lee, E. Y. (2006). Selection of Lecancillium strains for aphid (Myzus persicae) control. Korean J. Mycol., 34: 112118.

Quesada, M. E.and Vey, A. (2004). Bassiacridin, a protein toxic for locusts secreted by the entomopathogenic fungus Beauveria bassiana. Mycol. Res. 108 (4): 441- 452.

Quesada, M. E.; Maranhao, E. A. A.; García, P. V. and Álvarez, C. S. (2006). Selection of Beauveria bassiana isolates for control of the whiteflies Bemisia tabaci and Trialeurodes vaporariorum on the basis of their virulence, thermal requirements, and toxicogenic activity. Biol. Control, 36: 274 -287. 
Rachel, C. (1962). Silent spring. Publisher: Brian, L. and Jeff, M, New York. 40pp.

Sabbour, M. and Sahab, A.F. (2007). Efficacy of some microbial control agents against Agrotis ipsilon and Heliothis armigera in Egypt. Bull. Nat. Res. Cent., Cairo. 32(5): 559-569.

Shaw, E.; Davidson ,G.; Clark ,J.; Ball, V.; Pell, K.; Chandler ,D.and Sunderland, D. (2002). Laboratory bioassays to assess the pathogenicity of mitosporic fungi to Varroa destructor (Acari: Mesostigmata), an ectoparasitic mite of the honeybee, Apis mellifera. Biol. Cont. 24: 266-276.

Shia, W. B. and Feng, M.G. (2004). Lethal effect of Beauveria bassiana, Metarhizium anisopliae, and Paecilomyces fumosoroseus on the eggs of Tetranychus cinnabarinus (Acari: Tetranychidae) with a description of a mite egg bioassay system. Biol. Cont. 30:165-173.

Smith, S.M.; Moore, D.; Oduor, G.; Wright, D.; Chandi, E. and Agano, J.
(2006). Effect of wood ash and conidia of Beauveria bassiana (Balsamo) Vuillemin on mortality of Prostephanus truncatus (Horn). J. Stored Prod. Res. 42: 357-366.

Steenberg, T. and Humber, R. A. (1999). Entomopathogenic potential of Verticillium and Acremonium species (Deuteromycotina: Hyphomycetes). J. Invertebr. Pathol. 73: 309-314.

Tounou, A.; Kooyman,C.; DouroKpindou, O. K. and Poehling, $\mathrm{H}$. (2008). Interaction between Paranosema locustae and Metarhizium anisopliae var. acridum, two pathogens of the desert locust, Schistocerca gregaria under laboratory conditions. J. Invertebr. Pathol. 97: 203-210.

Tscharntke, T.; Klein, A.M.; Kruess, A.; Steffan-Dewenter, I. and Thies, C. (2005). Landscape perspectives on agricultural intensification and biodiversity ecosystem service management. Ecol. Lett. 8: 857- 874.

\section{ARABIC SUMMARY \\ Spodoptera التقييم الحيوى لبعض الفطريات الممرضه للحشرات ضد الطور اليرقى لاوده ورق القطن

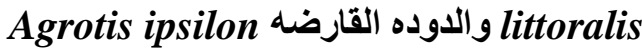

$$
\begin{aligned}
& \text { فاطمه محمد على الهوارى ـ أحمد محمد عزت عبد السلام }
\end{aligned}
$$

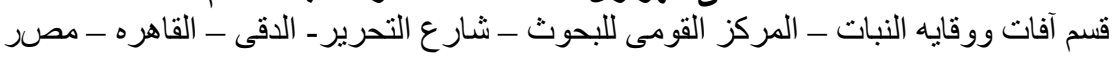

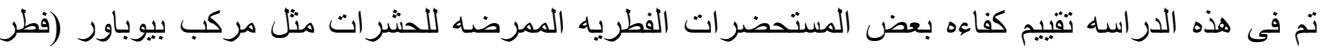
(Beauveria bassiana (Paecilomyces fumosoroseus

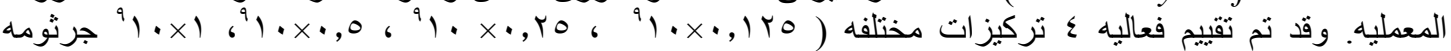

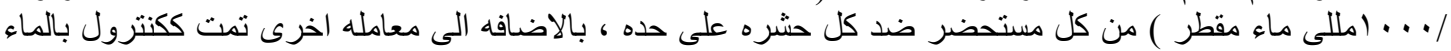

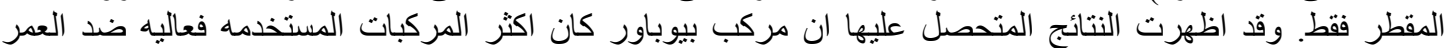

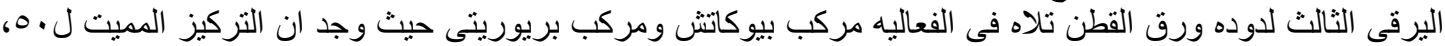

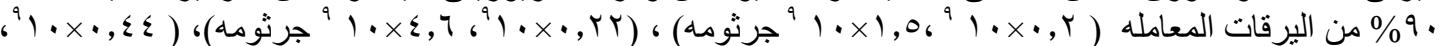

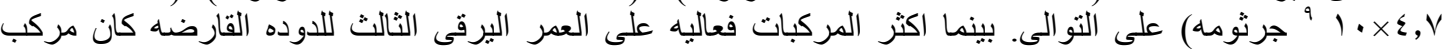

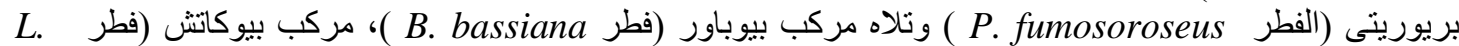
lecanii

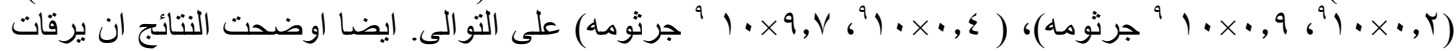

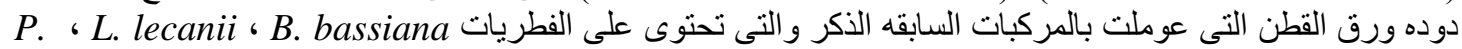
fumosoroseus

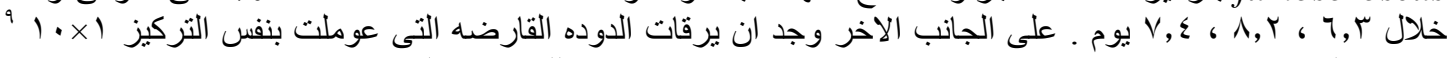

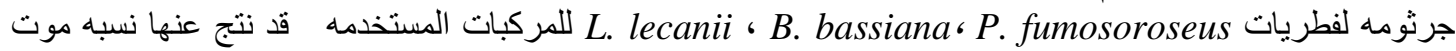

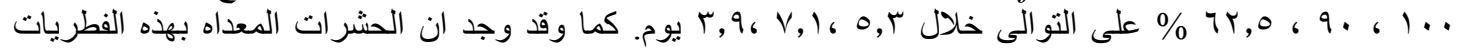

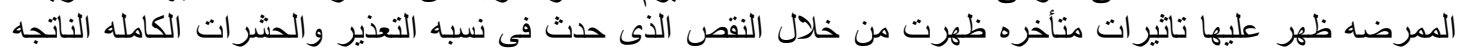

